Original

\title{
Lack of Enhanced Epithelial Cell Proliferation in the Urinary Bladder of Heterozygous p53 Knockout Mice Given Sodium Ortho-phenylphenate or Uracil
}

\author{
Satoshi Uwagawa ${ }^{1,2}$, Keisuke Ozaki ${ }^{1,2}$, Tokuo Sukata ${ }^{1,2}$, Masahiko Kushida ${ }^{1,2}$, \\ Yasuyoshi Okuno ${ }^{1}$, and Shoji Fukushima ${ }^{2}$ \\ ${ }^{1}$ Environmental Health Science Laboratory, Sumitomo Chemical Co., Ltd., 3-1-98, Kasugade-naka, Konohana-ku, \\ Osaka 554-8558, Japan \\ ${ }^{2}$ Department of Pathology, Osaka City University Medical School, 1-4-3, Asahi-machi, Abeno-ku, Osaka 545-8585, \\ Japan
}

\begin{abstract}
In the present study, we investigated epithelial cell proliferation in heterozygous p53 knockout (p53 ${ }^{+/-}$) mice after administration of two urinary bladder non-genotoxic carcinogens, in comparison with that in wild-type littermates $\left(\mathrm{p} 53^{+/+}\right)$. Mice at 10 -weeks of age were given $2 \%$ sodium ortho-phenylphenate (Na-OPP) or $2.5 \%$ uracil in the basal diet for 4 weeks. Uracil evoked a marked elevation of epithelial cell proliferation and development of papillary or diffuse epithelial hyperplasia associated with calculus formation in $\mathrm{p} 53^{+/}$as well as $\mathrm{p} 53^{+/+}$mice. Administration of Na-OPP caused alkalization of the urine in both. Neither Na-OPP nor uracil induced a higher epithelial cell proliferative response in $\mathrm{p} 53^{+/-}$mice as compared with $\mathrm{p} 53^{+/+}$mice. While we previously reported $\mathrm{p} 53^{+/-}$mice to be highly sensitive to a genotoxic urinary bladder carcinogen, N-butyl-N-(4-hydroxybutyl)nitrosamine, the present results suggest that $\mathrm{p} 53^{+/-}$ mice may not have a high susceptibility to induction of urinary bladder tumors by non-genotoxic carcinogens.
\end{abstract}

(J Toxicol Pathol 2003; 16: 147-152)

Key words: cell proliferation, sodium ortho-phenylphenate, uracil, urinary bladder, heterozygous p53 knockout mice

\section{Introduction}

Many experimental systems have been developed for the detection of carcinogenic potential of environmental chemicals, the long-term bioassay using both sexes of two rodent species still being most commonly used ${ }^{1}$. The protocol for this long-term bioassay has been standardized and the data generated are widely accepted for evaluation of carcinogenic potential of chemicals. However, the length of time required and magnitude of the cost are major disadvantages. Recently, the International Conference on Harmonization on Technical Requirements for the Registration of Pharmaceuticals for Human Use (ICH) recommended a change in the approach to assessing carcinogenic potential for pharmaceuticals, with the stress on one long-term bioassay (usually in rats) and additional in vivo short or medium-term bioassays ${ }^{2-4}$.

The p53 tumor suppressor gene has received much

Received: 10 December 2002, Accepted: 30 June 2003

Mailing address: Satoshi Uwagawa, Environmental Health Science

Laboratory, Sumitomo Chemical Co. Ltd., 3-1-98, Kasugade-naka,

Konohana-ku, Osaka 554-8558, Japan

TEL: 81-6-6466-5346 FAX: 81-6-6466-5446

E-mail: uwagawa@sc.sumitomo-chem.co.jp attention because of its propensity for genetic alteration in a wide variety of human neoplasms ${ }^{5,6}$. Wild-type $\mathrm{p} 53$ is a negative regulator of cell proliferation, causing cell cycle arrest in late G1 phase to allow repair when DNA is damaged. Cells lacking wild-type p53 function may be unable to arrest their progression through the cell cycle following DNA damage, resulting in fixation of genetic lesions. For this reason, p53 knockout mice are considered to be attractive for in vivo short or medium-term bioassay models ${ }^{7}$. Indeed the available p53 knockout mice are well established to be highly susceptible to spontaneous development of tumors ${ }^{8-10}$. One focus of attention is whether they also feature elevated sensitivity to chemical carcinogens and reports have already appeared that heterozygous $\mathrm{p} 53$ knockout $\left(\mathrm{p} 53^{+-}\right.$) mice demonstrate enhanced development and/or malignant progression of various tumors in targeted organs, including the skin, mesothelium, brain, urinary bladder, and blood vessels ${ }^{11-16}$.

Previously, we reported that $\mathrm{p} 53^{+/-}$mice are highly sensitive to induction of urinary bladder cell proliferation and tumors by a genotoxic carcinogen ${ }^{15}$, in line with previous reports ${ }^{17-20}$, but the question of whether $\mathrm{p} 53^{+/-}$mice are similarly sensitive to non-genotoxic urinary bladder carcinogens remained unclear. In the present study, we 
therefore investigated changes in urinary composition and levels of DNA synthesis and degree of morphological alteration in the urinary bladder epithelium of $\mathrm{p} 53^{+/}$mice following oral administration of two non-genotoxic urinary bladder carcinogens, sodium ortho-phenylphenate (Na-OPP) or uracil, and compared the results with the findings for wild-type $\left(\mathrm{p} 53^{+/+}\right)$mice.

\section{Materials and Methods}

\section{Animals and chemicals}

Male $\mathrm{p} 53^{+/-}$and $\mathrm{p} 53^{+/+}$mice were purchased from Taconic (Germantown, NY, USA) and housed in plastic cages ( 5 mice to a cage) with wood chips for bedding in a room kept at $24 \pm 2{ }^{\circ} \mathrm{C}$ temperature and $40-70 \%$ humidity with a 12-hr light-dark cycle (light on, 8:00-20:00). After a one-week acclimatization period, 10-week-old mice were used for the following experiment. Na-OPP was purchased from Tokyo Chemical Industry Co. (Tokyo) and uracil was obtained from Yamasa Shoyu Co. (Chiba).

\section{Experimental design}

Totals of $30 \mathrm{p} 53^{+/-}$and $\mathrm{p} 53^{+/+}$mice were randomly divided into 3 groups, as shown in Table 1. They were given powdered basal diet (Oriental MF, Oriental Yeast Co., Ltd., Tokyo) containing no supplement (control) or $2 \%$ Na-OPP or $2.5 \%$ uracil, for 4 weeks. The dose of uracil chosen is known to induce urinary bladder tumors in mice ${ }^{21}$, while $2 \%$ $\mathrm{Na}-\mathrm{OPP}$ has been reported to target the urinary bladder in male rats but not mice ${ }^{22,23}$. Food and water were available $a d$ libitum. During the experiment, body weights were measured weekly, and food consumption and water intake were assessed at week 4, when fresh urine was collected from mice in each group by forced micturition at 8 a.m. for measurement of urinary $\mathrm{pH}$ using a $\mathrm{pH}$ meter (Twin $\mathrm{pH}$, Horiba, Kyoto).

\section{DNA synthesis and pathological examination}

All mice received a single i.p. injection of 5-bromo-2'deoxyuridine (BrdU, Sigma Chemical Co., St Louis, MO, USA) at a dose of $100 \mathrm{mg} / \mathrm{kg}$ body wt, one hour prior to being killed ${ }^{15}$. Each urinary bladder was inflated by intraluminal injection of $10 \%$ phosphate-buffered formalin solution, and placed in the fixative. After two-hours fixation, they were bisected and one half was cut longitudinally into 2 strips, preserved again in the fixative overnight, then embedded in paraffin. Tissue sections cut at approximately $5 \mu \mathrm{m}$ were stained for immunohistochemistry using anti-BrdU antibody (DAKO A/S, Copenhagen, Denmark) and a Vectastain ABC kit (Vector laboratories Inc., Burlingame, CA, USA) with 3,3'-diaminobenzidine (Sigma Chemical Co., St Louis, MO, USA). For scoring BrdU labeling indices, 1000 epithelial cells were examined for each group under a light microscope (LM) and the labeling indices expressed as percentage values. Sections were also stained with hematoxylin and eosin for LM examination.

\section{Statistical analysis}

Statistical analysis was conducted using the Yukms statistical library I (Yukms Corporation, Tokyo). Body weights and BrdU labeling indices were analyzed using analysis of variance. With regard to parameters for which a significant difference was detected at the 5\% level, the least significant difference (LSD) method was used as a test for significant differences from the control values. Urine $\mathrm{pH}$ data were analyzed using the Kruskal-Wallis and MannWhitney tests.

\section{Results}

No deaths occurred during the treatment period. Clinical observation revealed soft feces for both $\mathrm{p} 53^{+/}$and p5 $3^{+/+}$mice treated with Na-OPP. Data on final body weights as well as food consumption and water intake are summarized in Table 1. The final body weights of the NaOPP and uracil treated groups were significantly reduced in both $\mathrm{p} 53^{+/-}$and $\mathrm{p} 53^{+/+}$mice as compared with those of the matched control values. Food consumption was slightly decreased in both $\mathrm{p} 53^{+/-}$and $\mathrm{p} 53^{+/+}$mice treated with uracil while water intake was moderately increased. In the case of $\mathrm{Na}-\mathrm{OPP}$, food consumption of both $\mathrm{p} 53^{+/-}$and $\mathrm{p} 53^{+/+}$mice was slightly lower than that of non-treated mice, with no difference between the treated groups.

\section{Urinalysis}

Data for urinary $\mathrm{pH}$ are shown in Table 2. In both $\mathrm{p} 53^{+/-}$and $\mathrm{p} 53^{+/+}$mice treatment with Na-OPP resulted in significant elevation as compared to the matched control values. In the uracil-treated case, urinary acidity was significantly increased.

\section{DNA synthesis}

Data for BrdU labeling indices are shown in Table 2. Values for both $\mathrm{p} 53^{+/-}$and $\mathrm{p} 53^{+/+}$mice given Na-OPP were not increased as compared with those of matched controls. While $\mathrm{p} 53^{+/-}$and $\mathrm{p} 53^{+/+}$mice given uracil showed marked increase in BrdU labeling indices, there was no significant difference between the $\mathrm{p} 53^{+/-}$and $\mathrm{p} 53^{+/+}$cases (Fig. 1).

\section{Pathological examination}

No calculus formation was evident in the urinary bladders of $\mathrm{p} 53^{+/-}$and $\mathrm{p} 53^{+/+}$mice treated with Na-OPP and microscopic features were comparable with those for controls. Uracil treatment caused calculus formation and microscopic examination revealed papillary or diffuse epithelial hyperplasia of the bladder epithelium in both $\mathrm{p} 53^{+/-}$and $\mathrm{p} 53^{+/+}$mice.

\section{Discussion}

The results of the present study clearly demonstrated a lack of elevated epithelial cell proliferation in the urinary bladder of $\mathrm{p} 53^{+/-}$mice as compared with $\mathrm{p} 53^{+/+}$mice after administration of two non-genotoxic urinary bladder 
Table 1. Data for Final Body Weights, Food Consumption, and Water Intake

\begin{tabular}{llcccc}
\hline Group & Chemical & No. of mice & $\begin{array}{c}\text { Final body weight }(\mathrm{g}) \\
\text { (mean } \pm \text { SD) }\end{array}$ & $\begin{array}{c}\text { Food consumption } \\
\text { (g/animal/day) }\end{array}$ & $\begin{array}{c}\text { Water intake } \\
\text { (ml/animal/day) }\end{array}$ \\
\hline${\mathrm{p} 53^{+/+}}$ & Control & 5 & $29.9 \pm 1.5$ & 3.6 & 5.4 \\
& $2 \%$ Na-OPP & 5 & $26.5 \pm 1.2^{* *}$ & 2.3 & 5.7 \\
$\mathrm{p} 53^{+/-}$ & 2.5\% Uracil & 5 & $25.7 \pm 1.2^{* *}$ & 3.3 & 7.7 \\
& Control & 5 & $29.8 \pm 1.4$ & 3.5 & 5.4 \\
& $2 \%$ Na-OPP & 5 & $27.6 \pm 0.8^{* *}$ & 2.9 & 4.9 \\
& $2.5 \%$ Uracil & 5 & $28.4 \pm 0.9^{*}, \# \#$ & 2.7 & 7.3 \\
\hline
\end{tabular}

Significantly different from the relevant control value at *, $\mathrm{P}<0.05, * *, \mathrm{P}<0.01$.

Significantly different from the value for $\mathrm{p} 53^{+/+}$mice treated with the same chemical at ${ }^{\#}, \mathrm{P}<0.01$.

Table 2. Data for Urinary $\mathrm{pH}$ and Urinary Bladder BrdU Labeling Indices

\begin{tabular}{llccc}
\hline Group & Chemical & No. of mice & $\begin{array}{c}\text { Urinary pH } \\
\text { (mean } \pm \text { SD) }\end{array}$ & $\begin{array}{c}\text { BrdU labeling index (\%) } \\
\text { (mean } \pm \text { SD) }\end{array}$ \\
\hline $\mathrm{p} 53^{+/+}$ & Control & 5 & $7.2 \pm 0.2$ & $0.11 \pm 0.13$ \\
& $2 \%$ Na-OPP & 5 & $8.1 \pm 0.2 * *$ & $0.13 \pm 0.05$ \\
$\mathrm{p} 53^{+/-}$ & $2.5 \%$ Uracil & 5 & $6.5 \pm 0.7 *$ & $17.37 \pm 2.48^{* *}$ \\
& Control & 5 & $7.4 \pm 0.1$ & $0.07 \pm 0.03$ \\
& $2 \%$ Na-OPP & 5 & $8.1 \pm 0.1 * *$ & $0.08 \pm 0.04$ \\
& $2.5 \%$ Uracil & 5 & $6.5 \pm 0.4 * *$ & $17.94 \pm 1.73^{* * a)}$ \\
\hline
\end{tabular}

Significantly different from the relevant control value at *, $\mathrm{P}<0.05$; **, $\mathrm{P}<0.01$.

a): Effective number of mice was four.

carcinogens, Na-OPP and uracil.

After administration of uracil, formation of urinary calculi, as well as papillary or diffuse hyperplasia and cell proliferation of the epithelium were observed in both $\mathrm{p} 53^{+/-}$ and $\mathrm{p} 53^{+/+}$mice. However, with neither parameter did the extent differ between $\mathrm{p} 53^{+/-}$and $\mathrm{p} 53^{+/+}$mice so that $\mathrm{p} 53^{+/-}$ mice do not have greater susceptibility to uracil-induction of epithelial cell proliferation in the urinary bladder. This may indicate that mechanical agents, such as uracil-induced calculi, affect the urinary bladder epithelium by a p53 independent pathway. Uracil has been reported to induce urinary bladder tumors in mice due to formation of urinary calculi that mechanically damage the epithelial cells of the urinary bladder, resulting in cell death and compensatory epithelial cell proliferation and tumor development ${ }^{21,24}$. The present results would suggest that $\mathrm{p} 53^{+/-}$mice might not be expected to develop more tumors than their wild-type counterparts on chronic exposure to such mechanical agents.

$\mathrm{Na}-\mathrm{OPP}$ is reported to be a urinary bladder carcinogen in male rats but not in females or in either sex of mice ${ }^{22,23}$. For sodium salt-induced urinary bladder carcinogenesis, changes of urinary components, with elevation of the urinary $\mathrm{pH}$ value and $\mathrm{Na}$ ion concentration, are considered essential factors for activity in male rats ${ }^{25-27}$. In fact, OPP itself does not show any modifying potential for urinary bladder carcinogenesis in rats $^{28,29}$. It has been reported that sodium L-ascorbate and Na-OPP treated mice show elevation of urinary $\mathrm{pH}$ value and $\mathrm{Na}$ ion concentration, but no morphological changes or enhanced urinary bladder carcinogenesis ${ }^{30,31}$. Regarding species and sex differences a urinary protein, $\alpha 2 \mathrm{u}$-globulin, is considered to be an essential factor ${ }^{27}$. In fact, sodium L-ascorbate caused no induction of epithelial cell proliferation or any promotion effects on urinary bladder carcinogenesis in NCI-Black Reiter (NBR) male rats that lack the capacity for $\alpha 2 \mathrm{u}-$ globulin synthesis ${ }^{32,33}$. It is well known that administration of Na-OPP or other sodium salts is associated with enhanced DNA synthesis in the urinary bladder epithelial cells, resulting in epithelial hyperplasia in rats ${ }^{34}$. Therefore, the present finding that $\mathrm{p} 53^{+/-}$mice showed elevation of urinary $\mathrm{pH}$, reflecting the elevation of $\mathrm{Na}$ ion concentrations in urine, but no increase in epithelial cell proliferation, supports the existence of species differences in Na-OPP induced urinary bladder carcinogenesis.

OPP is not genotoxic, although its semiquinone and quinone metabolites, phenylhydroquinone (PHQ) and phenylbenzoquinone (PBQ), might form DNA adducts ${ }^{35,36}$. Furthermore, it has been reported that after injection of PHQ and $P B Q$ into the urinary bladder of rats directly, DNA strand breaks were only detected at high doses of PBQ, which were very unlikely to be reached with oral uptake ${ }^{29}$. In the present study, production of these metabolites was not measured, but if they were present in the urine, DNA damage could have occurred in the urinary bladder epithelium, since $\mathrm{p} 53^{+/-}$mice have high susceptibility to genotoxic urinary bladder carcinogens. The present data indicating no elevation of epithelial cell proliferation as compared with that in the wild-type may thus point to a lack of high levels 


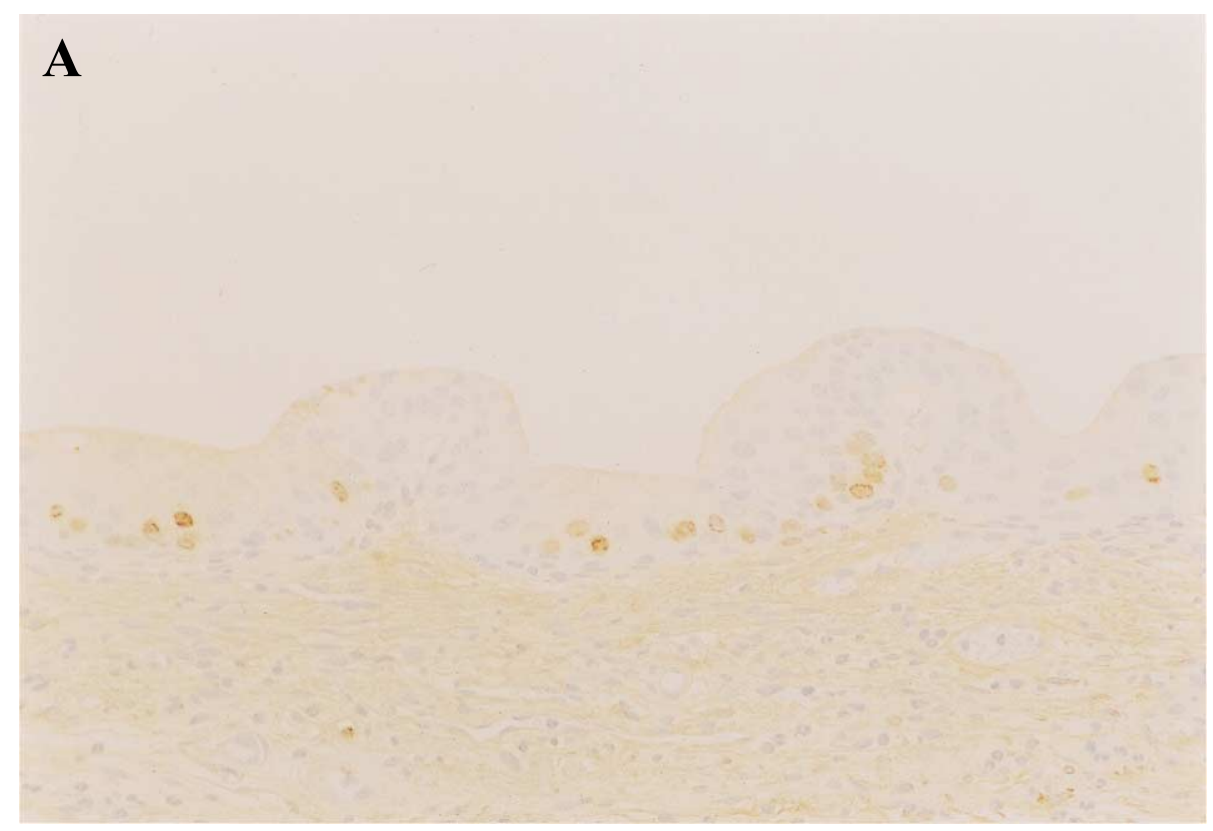

B

Fig. 1. BrdU immunostaining of urinary bladders of mice treated with $2.5 \%$ Uracil. A: p53 $3^{+/+}$. B: $\mathrm{p} 53^{+/-}$. Both A and B show marked increase in BrdU-stained epithelial cells.

of semiquinone and quinone metabolites in urine after oral administration of Na-OPP.

Recently, organ specificity has been reported regarding susceptibility to induction of cell proliferation in $\mathrm{p}^{5} 3^{+/}$mice, with the p53 gene playing a key role in regulation of cell growth in the urinary bladder and skin, but not the liver, lung, and kidney ${ }^{37}$. In fact, $\mathrm{p} 53^{+/-}$mice exhibit enhanced malignant progression of skin tumors induced by $\mathrm{DMBA}^{11}$ and ultraviolet radiation ${ }^{12}$ and development of urinary bladder tumors after treatment with $\mathrm{BBN}^{15}$ or $p$-cresidine ${ }^{20}$, but not liver lesions after treatment with genotoxic carcinogens, 2-amino-3-methylimidazo[4,5-f]quinoline
$(\mathrm{IQ})^{38}, 2$-amino-3,8-dimethylimidazo $[4,5-f]$ quinoxaline (MeIQx) $)^{39}$, dimethylnitrosamine ${ }^{40}, 2$-amino-1-methyl-6phenylimidazo $[4,5-b]$ pyridine $(\mathrm{PhIP})^{40}, 6$-nitrochrysene ${ }^{40}$ or N-di-N-butylnitrosamine ${ }^{41}$. These results clearly demonstrate organ specific sensitivity in $\mathrm{p} 53^{+/-}$mice, even if they are exposed to genotoxic carcinogens by which DNA damage would occur in the target organs. In the nonsensitive target organs, other cell cycle regulation factors may compensate for decrease of p53 function in $\mathrm{p} 53^{+/-}$mice. However, the present demonstration of no enhancement of cell proliferation in $\mathrm{p} 53^{+/-}$mice after treatment with two nongenotoxic carcinogens, Na-OPP and uracil, was in the 
urinary bladder, where p53 onco-suppressor gene does have an essential regulatory role.

The present data indicate that $\mathrm{p} 53^{+/-}$mice may not have high sensitivity to non-genotoxic carcinogens. However, one example of the latter, the immunosuppressive cyclosporin A, did enhance tumorigenesis in $\mathrm{p} 53^{+/}$mice $^{18}$. We speculate that this may have been due to its effects on lymphoid tissues, which spontaneously give rise to lymphomas in $\mathrm{p} 53^{+/-}$mice. Therefore, the question of whether $\mathrm{p} 53^{+/}$mice have high sensitivity to non-genotoxic carcinogens may depend on the target organ, and this now needs to be confirmed by long-term and studies with the emphasis on underlying mechanisms.

Acknowledgments: We acknowledge the assistance of Dr. M.A. Moore in the preparation of this manuscript. In addition, we thank Mr. K. Takeda and Mrs. K. Maeda for their expert technical assistance.

\section{References}

1. Faccini JM, Butler WR, Friedman JC, Hess R, Reznik GK, Ito N, Hayashi Y, and Williams GM. IFSTP guidelines for the design and interpretation of the chronic rodent carcinogenicity bioassay. Exp Toxic Pathol 1992; 44: 443456.

2. Monro AM and MacDonald JS. Evaluation of the carcinogenic potential of pharmaceuticals: Opportunities arising from the international conference on harmonisation. Drug Saf 1998; 18: 309-319.

3. Storer RD. Current status and use of short/medium term models for carcinogenicity testing of pharmaceuticals scientific perspective. Toxicol Lett 2000; 112-113: 557566.

4. van der Laan JW. Current status and use of short/medium term models for assessment of carcinogenicity of human pharmaceuticals: regulatory perspectives. Toxicol Lett 2000; 112-113: 567-572.

5. Donehower LA and Bradley A. The tumor suppressor p53. Biochim Biophys Acta 1993; 1155: 181-205.

6. Gottlieb TM and Oren M. p53 in growth control and neoplasia. Biochim Biophys Acta 1996; 1287: 77-102.

7. Alden C, Smith P, and Morton D. Application of genetically altered models as replacement for the lifetime mouse bioassay in pharmaceutical development. Toxicol Pathol 2002; 30: 135-138.

8. Donehower LA, Harvey M, Slagle BL, McArthur MJ, Montgomery Jr CA, Butel JS, and Bradley A. Mice deficient for p53 are developmentally normal but susceptible to spontaneous tumors. Nature 1992; 356: 215-221.

9. Donehower LA, Harvey M, Vogel H, McArthur MJ, Montgomery Jr CA, Park SH, Thompson T, Ford RJ, and Bradley A. Effects of genetic background on tumorigenesis in p53-deficent mice. Mol Carcinog 1995; 14: 16-22.

10. Harvey M, Vogel H, Morris D, Bradley A, Bernstein A, and Donehower LA. A mutant p53 transgene accelerates tumor development in heterozygous but not nullizygous p53deficent mice. Nat Genet 1995; 9: 305-311.

11. Kemp CJ, Donehower LA, Bradley A, and Balmain A. Reduction of $\mathrm{p} 53$ gene dosage does not increase initiation or promotion but enhances malignant progression of chemically induced skin tumors. Cell 1993; 74: 813-822.

12. Li G, Ho VC, Berean K, and Tron VA. Ultraviolet radiation induction of squamous cell carcinoma in p53 transgenic mice. Cancer Res 1995; 55: 2070-2074.

13. Marsella JM, Liu BL, Vaslet CA, and Kane AB. Susceptibility of $p 53$-deficient mice to induction of mesothelioma by crocidolite asbestos fibers. Environ Health Perspect 1997; 105 (Suppl 5): 1069-1072.

14. Oda H, Zhang S, Tsurutani N, Shimizu S, Nakatsuru Y, Aizawa $\mathrm{S}$, and Ishikawa $\mathrm{T}$. Loss of p53 is an early event in induction of brain tumors in mice by transplacental carcinogen exposure. Cancer Res 1997; 57: 646-650.

15. Ozaki K, Sukata T, Yamamoto S, Uwagawa S, Seki T, Kawasaki H, Yoshitake A, Wanibuchi H, Koide A, Mori Y, and Fukushima S. High susceptibility of $p 53(+/-)$ knockout mice to $N$-butyl- $N$-(4-hydroxybutyl)nitrosamine urinary bladder carcinogenesis and lack of frequent mutation in the residual allele. Cancer Res 1998; 58: 3806-3811.

16. Carmichael NG, Debruyne ELM, and Bigot-Lasserre D. The p53 heterozygous knockout mouse as a model for chemical carcinogenesis in vascular tissue. Environ Health Perspect 2000; 108: 61-65.

17. Floyd E, Mann P, Long G, and Ochoa R. The Trp53 hemizygous mouse in pharmaceutical development: Points to consider for pathologists. Toxicol Pathol 2002; 30: 147156.

18. Storer RD, French JE, Haseman J, Hajian G, LeGrand EK, Long GG, Mixson LA, Ochoa R, Sagartz JE, and Soper KA. $\mathrm{p} 53^{+/-}$hemizygous knockout mouse: Overview of available data. Toxicol Pathol 2001; 29 (Suppl.): 30-50.

19. Cohen SM. Alternative models for carcinogenicity testings: Weight of evidence evaluations across models. Toxicol Pathol 2001; 29 (Suppl.): 183-190.

20. Tennant RW, French JE, and Spalding JW. Identifying chemical carcinogens and assessing potential risk in shortterm bioassays using transgenic mouse models. Environ Health Perspect 1995; 103: 942-950.

21. Fukushima S, Tanaka H, Asakawa E, Kagawa M, Yamamoto A, and Shirai T. Carcinogenicity of uracil, a nongenotoxic chemical, in rats and mice and its rationale. Cancer Res 1992; 52: 1675-1680.

22. Fukushima S, Kurata Y, Ogiso T, Okuda M, Miyata Y, and Ito N. Pathological analysis of the carcinogenicity of sodium $o$-phenylphenate and $o$-phenylphenol. Oncology 1985; 42: 304-311.

23. Hagiwara A, Shibata M, Hirose M, Fukushima S, and Ito N. Long-term toxicity and carcinogenicity study of sodium $o$ phenylphenate in $\mathrm{B}_{6} \mathrm{C} 3 \mathrm{~F}_{1}$ mice. Food Chem Toxicol 1984; 22: 809-814.

24. Sakata T, Masui T, St John M, and Cohen SM. Uracilinduced calculi and proliferative lesions of the mouse urinary bladder. Carcinogenesis 1988; 9: 1271-1276.

25. Shibata M-A, Yamada M, Tanaka H, Kagawa M, and Fukushima S. Changes in urine composition, bladder epithelial morphology, and DNA synthesis in male F344 rats in response to ingestion of bladder tumor promoters. Toxicol Appl Pharmacol 1989; 99: 37-49.

26. Fukushima $\mathrm{S}$ and Murai $\mathrm{T}$. Calculi, precipitates and microcrystalluria associated with irritation and cell proliferation as a mechanism of urinary bladder carcinogenesis in rats and mice. In: Species Differences in 
Thyroid, Kidney and Urinary Bladder Carcinogenesis, CC Capen, E Dybing, JM Rice, and JD Wilbourn (eds), Lyon: IARC Scientific Publications No. 147, 159-174, 1999.

27. Cohen SM. Calcium phophate-containing urinary precipitate in rat urinary bladder carcinogensis. In: Species Differences in Thyroid, Kidney and Urinary Bladder Carcinogenesis, CC Capen, E Dybing, JM Rice, and JD Wilbourn (eds), Lyon: IARC Scientific Publications No. 147, 175-189, 1999.

28. Fukushima S, Inoue T, Uwagawa S, Shibata M-A, and Ito N. Co-carcinogenic effects of $\mathrm{NaHCO}_{3}$ on $o$-phenylphenolinduced rat bladder carcinogenesis. Carcinogenesis 1989; 10: $1635-1640$.

29. Bomhard EM, Brendler-Schwaab SY, Freyberger A, Herbold BA, Leser KH, and Richter M. $O$-phenylphenol and its sodium and potassium salts: A toxicological assessment. Crit Rev Toxicol 2002; 32: 551-626.

30. Shibata M-A, Hagiwara A, Tamano S, Fukushima S, and Ito N. Subchronic toxicity study of sodium $o$-phenylphenate in mice. Toxicol Lett 1985; 25: 239-246.

31. Tamano S, Asakawa E, Boomyaphiphat P, Masui T, and Fukushima S. Lack of promotion of N-butyl-N-(4hydroxybutyl)nitrosamine-initiated urinary bladder carcinogenesis in mice by rat cancer promoters. Teratog Carcinog Mutagen 1993; 13: 89-96.

32. Uwagawa S, Saito K, Okuno Y, Kawasaki H, Yoshitake A, Yamada H, and Fukushima S. Lack of induction of epithelial cell proliferation by sodium saccharin and sodium Lascorbate in the urinary bladder of NCI-Black-Reiter (NBR) male rats. Toxicol Appl Pharmacol 1994; 127: 182-186.

33. Uwagawa S, Saito K, Seki T, Kawasaki H, Takaba K, Wanibuchi H, and Fukushima S. Lack of promotion effects of sodium L-ascorbate on urinary bladder carcinogenesis in NCI-Black-Reiter (NBR) male rats initiated with N-butyl-N(4-hydroxybutyl)nitrosamine. J Toxicol Pathol 1997; 10: 103-107.

34. Chen TX, Wanibuchi H, Wei M, Morimura K, Yamamoto S,
Hayashi S, and Fukushima S. Concentration dependent promoting effects of sodium L-ascorbate with the same total dose in a rat two-stage urinary bladder carcinogenesis. Cancer Lett 1999; 146: 67-71.

35. Morimoto K, Sato M, Fukuoka M, Hasegawa R, Takahashi T, Tsuchiya T, Tanaka A, Takahashi A, and Hayashi Y. Correlation between the DNA damage in urinary bladder epithelium and the urinary 2-phenyl-1,4-benzoquinone levels from F344 rats fed sodium $o$-phenylphenate in the diet. Carcinogenesis 1989; 10: 1823-1827.

36. Murata M, Moriya K, Inuoe S, and Kawanishi S. Oxidative damage to cellular and isolated DNA by metabolites of a fungicide ortho-phenylphenol. Carcinogenesis 1999; 20: 851-857.

37. Sukata T, Ozaki K, Uwagawa S, Seki T, Wanibuchi H, Yamamoto S, Okuno Y, and Fukushima S. Organ-specific, carcinogen-induced increases in cell proliferation in $p 53$ deficient mice. Cancer Res 2000; 60: 74-79.

38. Morimura K, Salim EI, Yamamoto S, Wanibuchi H, and Fukushima S. Dose-dependent induction of aberrant crypt foci in the colons but no neoplastic lesions in the livers of heterozygous $p 53$-deficient mice treated with low dose 2amino-3-methylimidazo[4,5-f]quinoline. Cancer Lett 1999; 138: $81-85$.

39. Park CB, Kim DJ, Uehara N, Takasuka N, Hiroyasu B-T, and Tsuda H. Heterozygous $p 53$-deficent mice are not susceptible to 2-amino-3,8-dimethylimidazo[4,5f]quinoxaline (MeIQx) carcinogenicity. Cancer Lett 1999; 139: $177-182$.

40. Dass SB, Bucci TJ, Heflich RH, and Casciano DA. Evaluation of the transgenic $p 53^{+/-}$mouse for detecting genotoxic liver carcinogens in a short-term bioassay. Cancer Lett 1999; 143: 81-85.

41. Fukushima S. Possible involvement of $\mathrm{O}^{6}$-methylguanine formation and $p 53$ dysfunction in mouse urinary bladder carcinogenesis. Mutat Res 2001; 477: 125-130. 